\title{
A new mechanism based on landscape diversity for funding farmer subsidies
}

\author{
Alejandro J. Rescia ${ }^{1}$ - Javier Sanz-Cañada ${ }^{2}$ - Isabel Del Bosque-González ${ }^{3}$
}

Accepted: 24 January 2017 / Published online: 9 March 2017

(C) INRA and Springer-Verlag France 2017

\begin{abstract}
Agricultural intensification and farm abandonment in Europe have induced dramatic social, economic, and ecological issues. Sustainable management may solve these issues by providing a viable economic margin and preserving biodiversity. Specifically, we propose herein monetary compensation for farmers maintaining or restoring lands as nonagricultural areas. The mechanism for funding this compensation is based upon spatial analysis of two olive-grove landscapes. These exhibited different land-use patterns, a simple landscape and a complex one presenting a 50\% higher diversity index and an $80 \%$ higher complexity index. We estimated olive-oil production and profitability. Results showed that the complex landscape contains three times more protected habitats. Neither landscape was economically viable, with the simple one showing values of $43 \%$ below the threshold, and the complex one $185 \%$. The mechanism proposed to fund farmer subsidies was developed by means of the spatial and economic data estimated. This conservation payment system considers a non-linear relationship between the subsidies paid and the preserved area of agricultural use. The farmers of the simple landscape would receive a subsidy of 299,394 , and $464 € /$ ha for 10 , 20 , and $30 \%$ of preserved area, respectively. Inversely, the
\end{abstract}

Alejandro J. Rescia

alejo296@bio.ucm.es

1 Departamento de Ecología, Facultad de Ciencias Biológicas, Universidad Complutense de Madrid, C./José A. Novais, 12, 28040 Madrid, Spain

2 Instituto de Economía, Geografía y Demografía, Centro de Ciencias Humanas y Sociales, Consejo Superior de Investigaciones Científicas, C./Albasanz, 26-28, 28037 Madrid, Spain

3 Unidad de Sistemas de Información Geográfica, Centro de Ciencias Humanas y Sociales, Consejo Superior de Investigaciones Científicas, C./Albasanz, 26-28, 28037 Madrid, Spain farmers of the complex landscape would be granted a reduction of 38 and $80 € /$ ha in their monetary incentives for the loss of 10 and 20\%, respectively, of natural areas. Using this funding mechanism, conservation of biodiversity in agricultural areas would no longer constitute a factor limiting profitability, but would rather complement earnings.

Keywords Agriculture · Andalusia $\cdot$ Economic value of biodiversity - Environmental incentives · Olive groves . Profitability $\cdot$ Protected habitats

\section{Introduction}

Biodiversity constitutes an important input of agriculture and should be addressed, but it is often neglected by agricultural production policies. Consequently, management measures or spatial planning of conservation of biodiversity or habitats are seen as being opposed to rural development and are rejected by farmers.

In recent years, there has been growing interest in redirecting agricultural development toward sustainability by means of new approaches in resources management and environmentally friendly agricultural production. These new approaches seek to reconcile environmental impacts, biodiversity conservation, and productive agriculture (Scherr and McNeely 2008). One option of these approaches involves the land-sharing strategy, which integrates production and conservation by means of environmentally friendly agricultural management in specific croplands. The alternative option is the land-sparing strategy, which combines high-yield farming while protecting natural habitats from being used for agriculture (Green et al. 2005; Phalan et al. 2011). The land - sharing or sparing - options for agricultural areas are under conceptual and technical debate among the scholars (Von Wehrden et al. 2014). 
The different options for conciliation of agricultural production and biodiversity conservation are vital in Europe, because over $50 \%$ of the territory is considered to be predominantly rural and is associated with agricultural landscapes (Kotzeva 2013). These landscapes present a gradient of heterogeneity, from practically homogeneous monoculture to a diverse spatial pattern of rural activities interspersed with natural ecosystems, concentrating an important percentage of wild and agricultural biodiversity (Vos and Meekes 1999). In addition, the multifunctional condition of agricultural landscapes, associated with the delivery of ecosystem services (ES) such as rural culture, biodiversity conservation, carbon sequestration, and productivity, is currently widely admitted (García-Llorente et al. 2012; Zander et al. 2007). Within this context of multifunctionality in agriculture, farmers must be considered as producers and as managers of biodiversity conservation and as providers of ES. This multiple role of farmers must be assumed by society and should be economically supported by the administration (government or Environmental Agency). Moreover, this economic recognition could be the best way, if not the only one, to attenuate the unviable profitability of farmers in many agricultural areas. In addition, it would enable the biodiversity conservation and the ES provided by the heterogeneous components of agricultural landscapes to enhance profitability rather than reducing it (Daily and Ellison 2002).

Within the land-sharing/land-sparing debate, the profitability of agricultural areas is seldom mentioned, but it is evident that sustainable (viable) management in these areas also needs to involve a satisfactory level of profitability for the farmers, thus contributing to their sustainability in the long-term. This sustainable management to be applied in rural areas should also consider implementing payments for multifunctionality (different ES and biodiversity conservation) to farmers in order to complement their profits. Currently, numerous methods have been developed from different perspectives for the economic valuation of non-provisioning ES (GómezBaggethun et al. 2014), but a convincing system of payments for these services remains almost unaddressed, and the theme poses an immediate challenge to researchers, policy makers, consumers, and to the farmers themselves.

A paradigmatic case of multifunctional agricultural landscape with a small profit margin involves landscapes comprising olive crops (perennial fruit trees of Olea europaea L.) and semi-natural and natural ecosystems. These olive-grove landscapes are widespread in Spain and, in the Andalusia region, they cover over $1.5 \mathrm{M}$ ha, concentrating a high regional range of wild and agricultural biodiversity (14\% of olive groves are located in protected areas) (Bartolomé et al. 2015). In recent decades, the profitability of Andalusia olive crops has shown a marked decrease, leading farmers either to intensify management practices or to abandon their farms (Sánchez-Martínez et al. 2011). These phenomena, very common in rural areas throughout Europe, are threatening biodiversity conservation, food supply, agricultural markets, and social cohesion (Van Vliet et al. 2015), and, particularly, the Andalusia Administration is willing to pay a complementary environmental income to farmers in order to address this situation.

Considering all this, the present paper compares two olive-grove landscapes that are attempting to attain sustainable management, considering aspects of conservation, production, and profitability. We made a comparison at landscape scale between olive-grove landscapes with contrasting land-use strategies. Specifically, we analyzed the spatial pattern of the existing land uses and protected habitats; we estimated the agricultural production and economic profitability of the olive crops and employed our previously estimated spatial and economic data to propose a system of public payments to farmers in order to maintain a diversity of habitats at the landscape scale, and consequently to increase profitability and conserve biodiversity.

\section{Material and methods}

\subsection{Study area}

The study area included two districts (comarcas) in the Andalusia region, Estepa and Sierra de Segura, falling within the Protected Designations of Origin of ExtraVirgin Olive Oil (Fig. 1). The Estepa district occupies approximately 78,000 ha and is relatively flat (maximum altitudes of below $800 \mathrm{~m}$ a.s.1.), presenting an agricultural landscape in which olive crops are the predominant land use. There remains only a sparse remnant of natural vegetation (holm oak Mediterranean forests) and some seminatural areas, essentially dehesas (agro-silvo-pastoral systems comprising a continuous matrix of grassland with scattered trees). The Sierra de Segura district covers a mountainous area (ranging from 500 to $2000 \mathrm{~m}$ a.s.1.) of over 200,000 ha, with olive crops occupying a reduced area and many of these falling within the "Sierras de Cazorla, Segura y Las Villas" Natural Reserve. The natural vegetation is predominantly characterized by endemic Spanish black pine (Pinus nigra subs. salzmannii) and some formations of deciduous trees and sclerophyllous plants, together with dehesas. The predominant climate in both areas is Mediterranean with an average annual rainfall of between 500 and $700 \mathrm{~mm}$ (in the higher parts of the Sierra de Segura, it can reach $2000 \mathrm{~mm}$ ) and an annual mean temperature of $16^{\circ} \mathrm{C}$. 


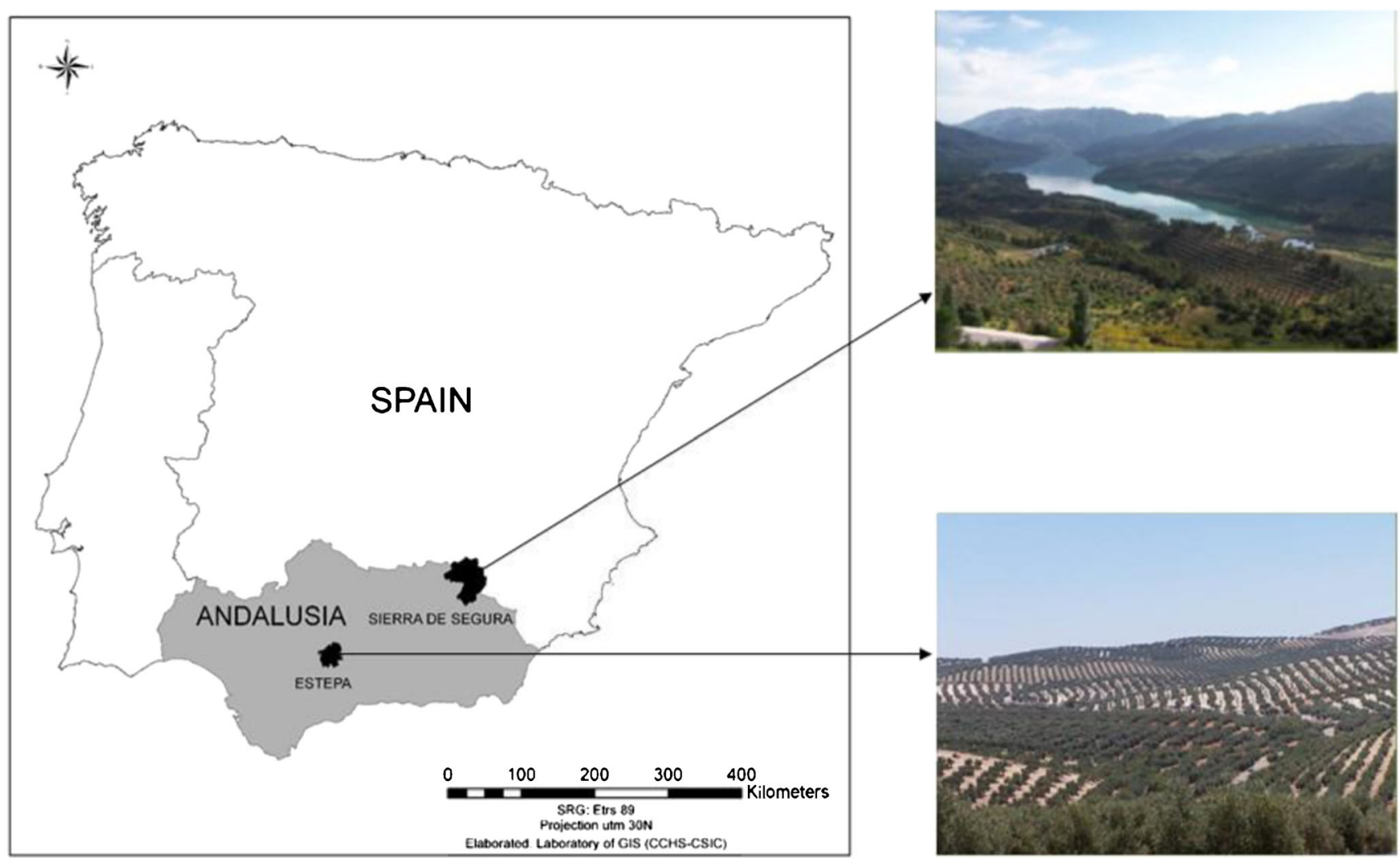

Fig. 1 Location and partial view of the agricultural landscapes studied. Estepa presents a land-use strategy more adapted to the land-sharing option (olive crops with semi-ecological management but scarce natural

\subsection{Data acquisition and analysis}

In order to analyze the spatial structure of the landscape, we used an original complete land-use map (from the year 2007) adapted from the Land Cover and Use Information System of Spain, developed by the Andalusia Environmental Department (LCUISS 2005). This classification was adjusted to the resolution level $(1: 25,000$ scale $)$ and the objectives of the research. We used landscape structure as an indicator of biodiversity conservation due to its matrix effects and habitat diversity (Cunningham et al. 2008). At the same time, the spatial structure detected enables us to infer ecological functions linked to the potential restoration and provision of ES (Hardman et al. 2016; Stallman 2011). Essentially, composition and spatial configuration of the landscape determine different horizontal flows (energy, materials), condition ecological processes, and provide regulation and supporting ES. To factually quantify the value of conservation of the landscape structure, we analyzed the presence and spatial configuration of habitats protected (or of conservation interest) by European and Spanish conservation regulations, using the map of protected habitats established by the European Union Habitats Directive (EUHD 1992). areas) and Sierra de Segura adapted to the land-sparing option (olive crops spatially concentrated and preserved natural areas)

Specifically, for these spatial analyses, we applied a set of selected landscape metrics (avoiding redundancy of information) from the Fragstats 4.0 software and other metrics based on the Theory of Information (for details of these metrics, see also McGarigal et al. 2012; Rescia et al. 2010). The landscape metrics used were as follows:

As a fragmentation index:

Interspersion and Juxtaposition Index (IJI) $=\frac{-\sum_{i=1}^{m} \sum_{k=i+1}^{m}\left[\left(\frac{\mathrm{e}_{\mathrm{ik}}}{\mathrm{E}}\right) \cdot \ln \left(\frac{\mathrm{e}_{\mathrm{ik}}}{\mathrm{E}}\right)\right]}{\ln (0.5[m(m-1)])} .100 ;$ where $e_{i k}$ : total length (m) of edge in landscape between land-use classes $i$ and $k ; E$ : total length (m) of edge; $m$ : number of land-use classes.

As a connectivity index:

Mean Euclidean nearest neighbor (ENN MN) $=\frac{\sum_{i=1}^{m} \sum_{j=1}^{n} \mathrm{~h}_{i j}}{\mathrm{~N}}$; where $h_{i j}$ : distance (shortest straight line) from patch $i j$ to nearest neighboring patch of the same type (class); $\mathrm{ENN}=h_{i j}$, at patch level.

As diversity and complexity indices:

Landscape diversity $\left(\mathrm{LH}^{\prime}\right)=-\sum\left[\mathrm{p}_{\mathrm{i} / j^{*}} \ln \left(\mathrm{p}_{\mathrm{i} / \mathrm{j}}\right)\right]$; where

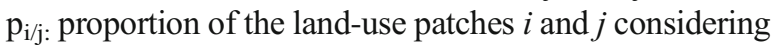
the total number of patches (NP) $\left(\sum \mathrm{p}_{\mathrm{i} j \mathrm{j}}=1\right)$ and landscape 
complexity $(\mathrm{LC})=\mathrm{LH}^{\prime 2} / \mathrm{lnNP}$; where $\mathrm{LH}^{\prime}$ : landscape diversity and NP number of patches.

As a dominant land-use of the landscape index:

Largest Patch Index (LPI) $=\frac{\max _{j=1}^{n}\left(a_{i j}\right)}{\mathrm{A}}(100)$; where aij $=$ area $\left(\mathrm{m}^{2}\right)$ of (largest) patch ij and $A=$ total landscape area $\left(\mathrm{m}^{2}\right)$.

To estimate agricultural production, two main farming management types of rain-fed olive crops can be identified in the study area: the traditional one (i.e., extensive) and the intensive one. Therefore, the rain-fed olive crops were classified according to terrain slope (possibility of using machinery, depending upon steepness) and tree density: non-mechanized traditional olive groves (NMTO) with slope $>20 \%$ and $<200$ trees/ha; mechanized traditional olive groves (MTO) with slope $<20 \%$ and $<200$ trees/ha; intensive olive groves (IO) with slope $<20 \%$ and $>200$ trees/ha. Each farming type presents a different olive-oil yield: $350 \mathrm{~kg}$ oil $/ \mathrm{ha}$ for NMTO; $700 \mathrm{~kg}$ oil/ha for MTO and $1000 \mathrm{~kg}$ oil/ha for IO. The three systems involve different operational costs (i.e., agrochemicals, labor, and machinery, among others). The classification criteria and data were based on studies and official statistical data at the local and regional levels (MAFE 2012; Sanz-Cañada et al. 2015).

For estimated profitability of olive oil production $(€ /$ ha), we analyzed the production stage of the value chain consisting on three stages: production (farming), transformation (industrial), and distribution (commercial). The reference farmer selling prices for the olive oil, as well as the costs, were considered for the 2007/08 period, as this corresponded to the landscape structure in the analyzed districts in 2007. Furthermore, the single payments introduced in the economic analysis, granted to farmers regardless of production type, refer to the European Single Payment Scheme established in the reform of the Common Agricultural Policy (ECR 2003). The values estimated were based on studies and official statistical data at the local and regional levels (POOLRED 2016; SanzCañada et al. 2015).

For valuation of environmental payments to olive farmers, we developed a mechanism, using an allometric equation, based on the criterion that the government (administration) would be willing to pay to a certain percentage of the areas preserved for agriculture following a scaling relationship, that is, a positive power function between the payment and the area preserved. The allometric equation proposed is:

BioEcoS- $P=a^{*} N A A^{b}$, where, BioEcoS-P (Biodiversity and Ecosystem Services Payments) is the dependent variable and denotes the environmental subsidy to be paid by the government $(€) ; a$ is a normalization constant parameter; NAA (NonAgricultural Area) is the independent variable representing the percentage of the total area covered by protected habitats, as well as semi-natural and natural vegetation excluding crops; and $b$ (being $b<1$ ) is the allometric exponent. This exponent represents the dynamic rules at play in the payment system, that is, the scaling relationship used to pay for the conservation area "designated" subjectively by the government. Subsequently, as the NAA increases, the BioEcoS-P increases in an approximately logarithmic manner. The starting value of BioEcoS-P and NAA in the allometric equation was determined by means of our results of the spatial analysis of the landscape and by the economic analysis of the olive-grove production system and considering the minimum threshold value of profitability economically viable for the Andalusia Region. The $b$ value was determined by fitting the allometric equation to the difference between the subsidies paid to farmers in both study cases.

\section{Results and discussion}

\subsection{Landscape structure}

Table 1 shows that almost $90 \%$ of Estepa comprises agricultural land-uses, whereas these only represent $27.66 \%$ in Sierra de Segura, considering that rain-fed olive crops represented $63.39 \%$ in the former case and $21.54 \%$ in the latter. In Sierra de Segura, the presence of wooded formations, dehesas, scrubland and grasslands was very significant $(68.46 \%)$, while in Estepa, natural and semi-natural land-uses covered only $6.87 \%$ of the territory. The value of the metrics evidenced that the landscape of Sierra de Segura was similarly fragmented (IJI), but better connected (lower value of ENN_MN) and more diverse and complex (greater value of $\mathrm{LH}^{\prime}$ and $\mathrm{LC}$ ) than the Estepa landscape. The relatively low value of fragmentation of Estepa resulted from the large clumped patches of olive crops but, at the same time, it presented small and disconnected areas of non-agricultural land-use patches (a high value of ENN_MN).

\subsection{Protected habitats, production, and profitability}

Table 2 reveals a highly contrasted presence of natural and semi-natural vegetation giving rise to a greater number (39 in Sierra de Segura and 13 in Estepa) and greater area (TPHA), representation (PPA), size (AREA_MN), clumping (IJI), diversity $\left(\mathrm{LH}^{\prime}\right)$ and complexity (LC) of protected habitats in Sierra de Segura. Table 3 shows that olive-oil production per hectare was greater in the Estepa district (732 and $468 \mathrm{~kg}$ of olive oil/ha, respectively) because the Estepa district presented a wide area covered by olive crops that are mechanized, presenting greater productivity than the nonmechanized crops, which represent the majority in Sierra de Segura. Moreover, in Estepa, there were considerably more 
Table 1 Spatial structure of the agricultural landscapes studied defined by different landscape metrics and relevant characteristics such as area, proportion of the total area, mean size, and largest patch of the main land-use types identified. Both landscapes were divided into agricultural and non-agricultural areas

\begin{tabular}{lll}
\hline $\begin{array}{l}\text { Spatial features and land-use/ } \\
\text { cover types }\end{array}$ & Estepa & $\begin{array}{l}\text { Sierra } \\
\text { de Segura }\end{array}$ \\
\hline $\begin{array}{ll}\text { Landscape structure } \\
\text { Fragmentation (\%) }\end{array}$ & & 60.58 \\
Connectivity (m) & 55.67 & 192.15 \\
Diversity (nat) & 289.54 & 2.03 \\
Complexity (nat) & 1.36 & 0.42 \\
Agricultural area (crops) & 0.23 & $46,704 / 21.54$ \\
Rain-fed olive crops (ha/\%) & & $704 / 0.33$ \\
Irrigated olive crops (ha/\%) & $49,554 / 63.39$ & $205 / 0.99$ \\
Abandoned olive crops (ha/\%) & $321 / 0.41$ & $12,376 / 5.7$ \\
Other crops (ha/\%) & $99 / 0.13$ & 35.89 \\
Mean area of olive crops (ha) & $17,784 / 22.74$ & 5.47 \\
Largest patch (olive crop) (\% of total area) & 113.15 & \\
Non-agricultural area (semi and natural cover) & 16.44 & $41,830 / 19.3$ \\
Forests and plantations (ha/\%) & & $44,282 / 10.43$ \\
Grasslands and scrubland (ha/\%) & $682 / 0.87$ & $62,290 / 28.74$ \\
Dehesas (semi-natural cover) (ha/\%) & $2541 / 3.25$ & $8392 / 3.87$ \\
Other non-production land-uses (ha/\%) & $2151 / 2.75$ & 13.65 \\
Mean area of natural patches (ha) & $5043 / 6.46$ & 7.23 (Pinus forest) \\
Largest patch (\% of total area) & 7.64 & \\
\hline
\end{tabular}

highly productive intensive olive systems than in Sierra de Segura (7473 and 467 ha, respectively), thus accentuating the difference in production.

Taking into account that production costs depend on the quantity and the way of the olive oil produced, these costs were substantially higher in Estepa (1536 and 1227 $€ /$ ha, respectively) due to the abundance of mechanized and intensive management systems. Finally, total profitability was observed to be greater in Estepa than in Sierra de Segura (704 and $350 € /$ ha, respectively), although the low level of profitability should be highlighted in both cases. The direct European Single Payments slightly compensate for the low income in the both districts but it should, however, be pointed out that profitability in the Sierra de Segura district was negative (-42€/ha) when these payments were discounted.

Table 2 Conservation value of the agricultural landscapes studied estimated from the spatial structure of the habitats protected by European and Spanish regulation

\begin{tabular}{lll}
\hline & Estepa & Sierra de Segura \\
\hline $\begin{array}{l}\text { Protected habitats } \\
\text { Total area (ha) }\end{array}$ & 4022 & 139,997 \\
Percentage of total area (\%) & 5.14 & 64.58 \\
Richness of patches & 13 & 39 \\
Mean area of patches (ha) & 5.99 & 56.47 \\
Interspersion of patches (\%) & 27.79 & 63.38 \\
Diversity of patches (nat) & 1.41 & 2.31 \\
Complexity of patches (nat) & 0.31 & 0.69 \\
\hline
\end{tabular}

\subsection{Payment mechanism for biodiversity conservation}

Figure 2 shows the proposed BioEcoS- $P$ scaling payments to farmers for the percentage of natural area excluded (or restored) from the agricultural use. According to this scheme of payments, the farmers would receive high monetary incentives for the first $10 \%$ of area excluded from agriculture and

Table 3 Production value and economic profitability of both agricultural landscapes estimated from the stage of production of the value chain analysis of extra-virgin olive oil. Only rain-fed olive grove equivalent area was considered (value adjusted to the smaller olive crops area of Sierra de Segura)

\begin{tabular}{|c|c|c|}
\hline & Estepa & Sierra de Segura \\
\hline \multicolumn{3}{|l|}{ Olive crops } \\
\hline Total area (ha) & \multicolumn{2}{|c|}{46,704} \\
\hline \multicolumn{3}{|l|}{ Crop systems (ha) } \\
\hline Non-mechanized management & 2335 & 31,292 \\
\hline Mechanized management & 36,896 & 14,945 \\
\hline Intensive management & 7473 & 467 \\
\hline Production (kg olive oil/ha) & 732 & 468 \\
\hline Farmer selling price $(€ / \mathrm{kg}$ olive oil) & \multicolumn{2}{|c|}{2.53} \\
\hline Production costs $(€ / \mathrm{ha})$ & 1536 & 1227 \\
\hline \multicolumn{3}{|l|}{ Single payments $(€ / \mathrm{kg})$} \\
\hline Non-mechanized management & \multicolumn{2}{|c|}{1.12} \\
\hline Mechanized management & \multicolumn{2}{|c|}{0.56} \\
\hline Intensive management & \multicolumn{2}{|c|}{0.39} \\
\hline Production incomes $(€ / \mathrm{ha})$ & 2240 & 1577 \\
\hline Profitability $(€ /$ ha) & 704 & 350 \\
\hline
\end{tabular}




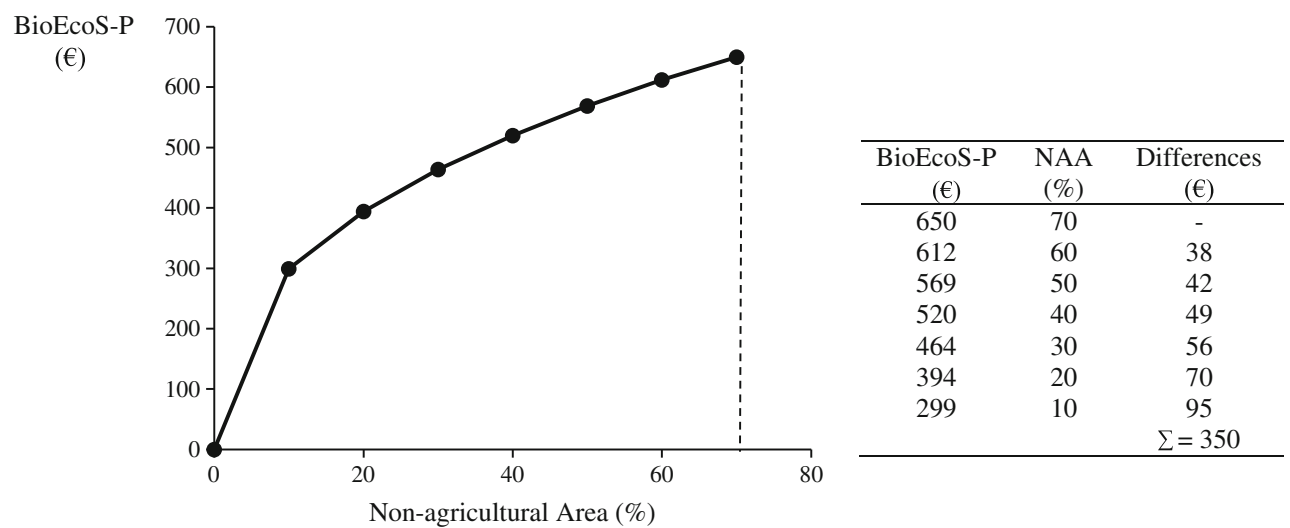

Fig. 2 Mechanism of payments of the biodiversity conservation and ecosystem services (BioEcoS-P) according to percentage of nonagricultural area (NAA) preserved in relation to the total area of the agricultural landscape considered. The percentage of preserved area increases and payments for this conservation decision increase, following a power relation for $a=119 €$ and $b=0.40 €$. The $b$ value was determined to compensate the difference in profitability/ha between both districts, taking into account their non-agricultural area. The values on the right of the figure correspond to the indicated points and were calculated following the formula: $\operatorname{BioE} \operatorname{coS}-P=a^{*} N A A^{b}$ would progressively receive lower payments for every $10 \%$ of land preserved. In the Andalusia region, the minimum threshold value of profitability considered economically viable for olive crops corresponds to an average value of practically $1100 € /$ ha (ESC 2011). Assuming that the administration would consider a threshold profitability value of 1000 ha, slightly lower than this regional minimum, but better adjusted to the national average value, in Estepa, presenting approximately $10 \%$ of non-agricultural land, the farmers would initially receive a habitat conservation subsidy of $299 € / \mathrm{ha}$, and in Sierra de Segura, with approximately $70 \%$ of nonagricultural land, they would be paid $650 € /$ ha. Thus, in accordance with the allometric scaling payments proposed, in Estepa, the farmers would receive $394 € /$ ha for abandoning the first $10 \%$ of agricultural land, $464 € /$ ha for the following $10 \%$ of agricultural systems abandoned, and so on. Inversely, Sierra de Segura would see a reduction of 38 and $80 € /$ ha in their monetary incentives for the loss of 10 and 20\%, respectively, of natural areas, and so forth (see Fig. 2).

\subsection{Economic valuation of biodiversity conservation as a profitable solution for agricultural landscapes}

Many studies of agricultural landscapes have detected the direct and positive relationship between spatial heterogeneity (variety of land uses) and complexity (degree of connectivity), on one hand, and biodiversity (Benton et al. 2003), potential capacity for restoration (Hardman et al. 2016) and the provision of ES, such as biological pest control and pollination (Kremen et al. 2007), on the other. Indeed, several authors (Groves et al. 2002) have indicated that, for an effective biodiversity and ES conservation in agricultural landscapes, there is a need to consider a broader spatial perspective than mere environmental practices in the farming system, i.e., the landscape context.

At the same time, Daily and Ellison (2002) emphasized that the economic profitability of farmers is vital to sustainable management of biodiversity in agricultural landscapes. Within this vision of profitable conservation in agricultural landscapes, we consider that an effective solution to the unprofitability in the olive grove landscapes studied could simultaneously be based on intensifying agricultural patches (improving profitability) and maintaining natural patches or restoring these by abandoning olive crops (improving biodiversity conservation). This kind of "win-win or bioprofit strategy," which would be applied to different agricultural landscapes (see Mouysset et al. 2014), would be highly appropriate for the olive groves studied in Andalusia. Specifically, in Estepa, farmers should gradually, and in controlled manner, abandon the less productive olive crops with a slope $>20 \%$ (over $2000 \mathrm{ha}$ ), with close to $100 \mathrm{t} \mathrm{ha}^{-1}$ year $^{-1}$ of soil erosion (Gómez and Giráldez 2010) intensifying other current crops on more arable land. In Sierra de Segura, farmers could increase productivity and profitability by intensifying farming management of olive crops located on non-sloping terrain (over 10,000 ha $<20 \%$ slope) and maintaining large natural areas for biodiversity conservation.

However, it is not enough to implement this strategy based upon intensification practices and crop abandonment to achieve a viable degree of profitability in the olive-grove landscapes studied. By intensifying olive crops, farmers would receive an increase of approximately $12 € / 1000$ ha (calculations based on the data in Tables 2 and 3) and, in addition, they would cause environmental degradation and have an impact on landscape diversity, affecting biodiversity, as well as the delivery of multiple ES. Therefore, public (or private) economic compensation for farmers for the cost of 
maintaining and restoring natural areas for conservation objectives, or for profits lost thereby, is a necessary alternative with regard to improving profitability. The system of payments or financial incentives for restoring or maintaining natural areas proposed in our study aims to meet both objectives: conservation benefits and profitable farming. This system of incentives is based on a criterion involving adjusting payments to a progressive process of diversification of the agricultural landscape, in accordance with a scaling law (see Fig. 2). Other incentive-based policy designs for environmental subsidies were developed or discussed (De Vries and Hanley 2016; Pascual and Perrings 2007), but always within the framework of uniform (not differentiated) payments and without spatial reference. The type of regime of progressive payments proposed here is essential with regard to determining the cost of the "biodiversity conservation" that should be paid to farmers to improve their profitability.

\section{Conclusions}

Different spatial structures of agricultural landscapes have different consequences for biodiversity conservation, potential ecological restoration and provision of ES. Our results showed the advantages for habitat conservation (13 vs. 39 protected habitats) in the more diverse and complex landscape structure. In economic terms, despite the general subsidies paid by the European Union, the different spatial structures analyzed (basically monoculture vs. crops mixed with natural vegetation) are impracticable due to the fact that profitability for farmers is far from the minimum level considered to be viable in this region.

We propose an economic incentive-based mechanism, to be managed by the administration (public policies) to promote levels of landscape diversity and complexity that are more suitable for biodiversity conservation. These economic incentives would complement the profits of farmers and can constitute, pending further validation, a sustainable solution for conciliating conservation, production and profitability in agricultural areas. In this context, conservation of biodiversity in agricultural landscapes ceases to represent a factor limiting the profitability of farmers, but rather serves to increase profits. In Andalusia, this system of incentives could be applied immediately under the auspices of the recent Olive-Grove Master Plan (ORGAB 2015), which specifically mentions economic support for farmers implementing environmentally friendly farming practices and applying improved spatial management; the aforementioned practices are intended to promote biodiversity, provide ES and to maintain landscape quality (assuming a heterogeneous structure).
Acknowledgements The present study was supported by the research project of the National Plan $(\mathrm{R}+\mathrm{D}+\mathrm{i})$ of the Government of Spain (AGL2012-36537, PI: Sanz-Cañada, J.): local agro-food systems and public goods and analysis and valuation models of territorial externalities in designations of origin of olive oil (EXTERSIAL II). The authors would like to thank the valuable comments of the editor in chief and three anonymous referees and we also thank E. Warman, M. Ortega, and A. López-Pintor for their insightful observations on an earlier version of this paper.

\section{References}

Bartolomé J, Fuentelsaz F, Hernández L, Peiteado C (2015) Olivares de montaña: pendientes de biodiversidad (Mountain olive groves: slopes of biodiversity). http://awsassets.wwf.es/downloads/ manual_olivares_montana_wwf.pdf. Accessed 07 Aug 2016

Benton TG, Vickery J, Wilson JD (2003) Farmland biodiversity: is habitat heterogeneity the key? Trends Ecol Evol 18:182-188. doi:10.1016/ S0169-5347(03)00011-9

Cunningham RB, Lindenmayer DB, Crane M, Michael D, MacGregor C, Montague-Drake R, Fischer J (2008) The combined effects of remnant vegetation and tree planting on farmland birds. Conserv Biol 22:742-752. doi: $10.1111 / j .1523-1739.2008 .00924 . x$

Daily GC, Ellison K (2002) The new economy of nature: the quest to make conservation profitable. Island Press, Washington DC

De Vries F, Hanley N (2016) Incentive-based policy design for pollution control and biodiversity conservation: a review. Environ Resource Econ 63:687-702. doi:10.1007/s10640-015-9996-8

ECR (European Commission Regulation) (2003) Council Regulation 1782/2003 Common rules for direct support schemes under the CAP. http://ec.europa.eu/agriculture/direct-support/legal-basis/ index enhtm. Accessed 07 Aug 2016

ESC (Economic and Social Council of Province of Jaén) (2011) Análisis de la rentabilidad económica de las explotaciones de olivar de la provincia de Jaén (Analysis of economic profitability of olive farms in the province of Jaén). CES, Jaén, Spain

EUHD (European Union Habitats Directive) (1992) Council Directive 92/43/EEC On the conservation of natural habitats and wild flora and fauna. http://eur-lex.europa.eu/legal-content/EN/TXT/?uri= CELEX:31992L0043. Accessed 07 Aug 2016

García-Llorente M, Martín-López B, Iniesta-Arandia I, López-Santiago C, Aguilera P, Montes C (2012) The role of multi-functionality in social preferences toward semi-arid rural landscapes: an ecosystem service approach. Environ Sci Pol 19-20:136-146. doi:10.1016/j. envsci.2012.01.006

Gómez; JA Giráldez JV (2010) Erosión y degradación de suelos (Erosion and degradation of soils) In: Sostenibilidad de la producción de olivar en Andalucía (Sustainability of olive grove production in Andalusia). Taguas 2000, Spain, pp: 68-125

Gómez-Baggethun E, Martín-López B, Barton D, Braat L, Saarikoski H, Kelemen E, García-Llorente M, van den Bergh J, Arias P, Berry R, Potschin M, Keene H, Dunford R, Schröter-Schlaack C, Harrison P (2014) EU FP7 OpenNESS Project Deliverable 41 State-of-the-art report on integrated valuation of ecosystem services European Commission FP7. http://www.openness-project.eu/sites/default/ files/Deliverable\%204\%201 Integrated-Valuation-Of-EcosystemServices.pdf.Accessed 07 Aüg 2016

Green RE, Cornell SJ, Scharlemann JPW, Balmford A (2005) Farming and the fate of wild nature. Science 307:550-555. doi:10.1126/ science. 1106049

Groves CR, Jensen DB, Valutis LL, Redford KH, Shaffer ML, Scott JM, Baumgartner JV, Higgins JV, Beck MW, Anderson MG (2002) Planning for biodiversity conservation: putting conservation science 
into practice. Bioscience 52:499-512. doi:10.1641/00063568(2002)052\%5B0499:PFBCPC\%5D2.0.CO;2

Hardman CJ, Harrison DPG, Shaw PJ, Nevard TD, Hughes B, Potts SG, Norris K (2016) Supporting local diversity of habitats and species on farmland: a comparison of three wildlife-friendly schemes. J Appl Ecol 53:171-180. doi:10.1111/1365-2664.12557

Kotzeva M (ed) (2013) Eurostat regional yearbook 2013. Publications Office of the European Union, Luxembourg

Kremen C, Williams NM, Aizen MA, Gemmill-Herren B, LeBuhn G, Minckley R, Packer L, Potts SG, Roulston T, Steffan-Dewenter I, Vázquez DP, Winfree R, Adams L, Crone EE, Greenleaf SS, Keitt TH, Klein A-M, Regetz J, Ricketts TH (2007) Pollination and other ecosystem services produced by mobile organisms: a conceptual framework for the effects of land-use change. Ecol Lett 10:299 314. doi:10.1111/j.1461-0248.2007.01018.x

LCUISS (Land Cover and Use Information System of Spain) (2005). http://www.siose.es/siose/. Accessed 07 August 2016

MAFE (Ministry of Agriculture Food and Environment) (2012) Agricultural Statistics. http://www.magrama.gob.es. Accessed 07 Aug 2016

McGarigal K, Cushman SA, Ene E (2012) FRAGSTATS v4: Spatial Pattern Analysis Program for Categorical and Continuous Maps Computer software program produced by the authors at the University of Massachusetts Amherst. http://www.umass.edu/ landeco/research/fragstats/fragstatshtml. Accessed 07 Aug 2016

Mouysset L (2014) Agricultural public policy: green or sustainable? Ecol Econ 102:15-23. doi:10.1016/j.ecolecon.2014.03.004

ORGAB (Official Regional Government of Andalusia Bulletin) (2015) Master Plan of Olive Grove Decree 103/2015. http://www. juntadeandalucia.es/boja/2015/54/BOJA15-054-00410.pdf. Accessed 07 Aug 2016

Pascual U, Perrings C (2007) Developing incentives and economic mechanisms for in situ biodiversity conservation in agricultural landscapes. Agr Ecosyst Environ 121:256-268. doi:10.1016/j.agee. 2006.12.025

Phalan B, Onial M, Balmford A, Green RE (2011) Reconciling food production and biodiversity conservation: land sharing and land sparing compared. Science 333:1289-1291. doi:10.1126/science. 1208742

POOLRED (Price Information System in Cash Market Origin Olive Oil) (2016). http://www.poolred.com/. Accessed 07 Aug 2016

Rescia AJ, Willaarts BA, Schmitz MF, Aguilera PA (2010) Changes in land uses and management in two Nature Reserves in Spain: evaluating the social-ecological resilience of cultural landscapes. Landscape Urban Plan 98:26-35. doi:10.1016/j.landurbplan.2010. 07.007

Sánchez-Martínez J, Gallego-Simón V, Araque-Jiménez E (2011) The Andalusian olive grove and its recent changes. Geogr Stud 270: 203-229

Sanz-Cañada J, García-Brenes D, Barneo-Alcántara M (2015) Value chain and typicity analysis in Jaén mountain olive oil Spain. New Medit 3:50-60

Scherr SJ, McNeely JA (2008) Biodiversity conservation and agricultural sustainability: towards a new paradigm of 'ecoagriculture' landscapes. Philos Trans R Soc Lond B Biol Sci 363:477-494. doi:10. 1098/rstb.2007.2165

Stallman HR (2011) Ecosystem services in agriculture: determining suitability for provision by collective management. Ecol Econ 71:131139. doi:10.1016/j.ecolecon.2011.08.016

Van Vliet J, de Groot HLF, Rietveld P, Verburg PH (2015) Manifestations and underlying drivers of agricultural land use change in Europe. Landscape Urban Plan 133:24-36. doi:10.1016/j.landurbplan.2014. 09.001

Von Wehrden H, Abson DJ, Beckmann M, Cord AF, Klotz S, Seppelt R (2014) Realigning the land-sharing/land-sparing debate to match conservation needs: considering diversity scales and land-use history. Landscape Ecol 29:941-948. doi:10.1007/s10980-014-0038-7

Vos W, Meekes H (1999) Trends in European cultural landscape development: perspectives for a sustainable future. Landscape Urban Plan 46:3-14. doi:10.1016/S0169-2046(99)00043-2

Zander P, Knierim A, Groot JCJ, Rossing WAH (2007) Multifunctionality of agriculture: tools and methods for impact assessment and valuation. Agric Ecosyst Environ 120:1-4. doi:10.1016/ j.agee.2006.10.010 